\title{
Warmth and Affection: A Comparative Study on Soft Skills and Social Skills among Children
}

\author{
Poonam Rani* and Bimla Dhanda \\ Department of Human Development and Family Studies, I.C. College of Home Science, \\ CCSHAU, Hisar, Haryana - 125004, India \\ *Corresponding author
}

\section{A B S T R A C T}

\section{Keywords}

Soft skills, Social skills, Warmth and affection, Protect, Guide,

Communicable, Teach and play

Article Info

Accepted:

06 May 2018

Available Online:

10 June 2018

\begin{abstract}
Warmth and affection are aspect of positive relationship that is essential for children wellbeing in early care and education settings. The study was conducted in Hisar district of Haryana state. Two areas were selected purposively i.e., rural and urban, from urban area Hisar city and from rural area two villages namely Balsmand and Kharia were taken for collection of data. A total of 200 children in three age groups, namely, 3, 4 and 5 years were selected for the study. Age, gender and area were taken as independent variable. Soft skills and social skills were taken as dependent variable. Vineland Adaptive Behavior Scale of Social Maturity (Sparrow et al., 1935) was used to determine soft skills and social skills among children. Result revealed that soft skills were significantly related with learning stimulation in rural areas but not significantly in urban areas and social skills were not related with learning stimulation in rural and urban areas.
\end{abstract}

\section{Introduction}

Expressing warmth and affection to children is important for many reasons. It's crucial for children of all ages to be appropriately touched and hugged by adults. Touching and holding infants and toddlers helps them feel secure and learn to trust their caregivers. A positive and supportive relationship promotes brain development. By remaining calm and responsive to the child's needs, adults can reassure and calm an anxious child. Finally, these activities will help you develop a good relationship with the children, and this will help you feel good, enjoy your work, and have fun.
Warmth and affection are aspect of positive teacher-child relationship that is essential for children wellbeing in early care and education settings. Expression of warmth and affection occurs as teacher's protect, guide, communicable, teach and play with children.

Warmth and affection should occur in the context of your daily routines, activities, and interactions. If your classroom is organized to promote children's appropriate behaviors, you will find it easier to interact more positively with children. If they are not, you may find that you spend much of your time responding to children's inappropriate behavior with directions, corrections and fussing. 
Parenting practices such as reading to children, using complex language, responsiveness, and warmth in interactions, is all associated with better developmental outcomes (Bradley 2002). Stimulating activities may help children with specific skills (e.g. linking letters to sounds) but also, and perhaps most importantly, by developing the child's ability and motivation concerned with learning generally.

Soft skills are a combination of people skills, social skills, communication skills, character traits, attitudes, career attributes, social intelligence and emotional intelligence quotients among others that enable people to navigate their environment, work well with others, perform well, and achieve their goals (Rosario, 2010).

Social skills are the abilities and traits that pertain to personality, attitude, and behavior. These skills encompass a wide range of social, communication and adaptive skills (Dubrin, 2014). Children's future earning power is increasingly likely to be determined by whether or not they possess soft skills, rather than just their exam results. Full potential must include not only letters and numbers, but also the soft skills that are foundational to so many advantages in the life (Shonkoff and Phillips, 2010).

\section{Objectives}

To assess the warmth and affection among children of rural and urban area.

To find out the influence of warmth and affection on the soft skills and social skills of children.

\section{Materials and Methods}

The study was conducted in Hisar district of Haryana state. Two areas were selected purposively i.e., rural and urban, from urban area Hisar city and from rural area two villages namely Balsmand and Kharia were taken for collection of data. A total of 200 children in three age groups, namely, 3, 4 and 5 years were selected for the study. 100 children were taken from the rural area and 100 children were selected from the urban area. Warmth and affection was taken as independent variable. Soft skills and social skills were taken as dependent variable. Vineland Adaptive Behavior Scale of Social Maturity (Sparrow et al., 1935) was used to determine soft skills and social skills among children. Home inventory by Caldwell and Bradley (1984) was used to assess the warmth and affection among children's.

\section{Results and Discussion}

Table 1 revealed that majority of rural and urban children fall in medium category of warmth and affection. Table 2 revealed that soft skills were not significantly associated with warmth and acceptance in rural and urban area. Social skills were significantly associated with warmth and acceptance in rural area but, social skills were not significantly associated with warmth and acceptance in urban area.

Table.1 Profile of respondents according to their home environment

\begin{tabular}{|c|l|c|c|}
\hline Sr. No. & Sub Scale & Rural $(\mathbf{n = 1 0 0})$ & Urban $(\mathbf{n = 1 0 0})$ \\
\hline 1. & Warmth and Affection & & \\
\hline & Low (0-3) & 26 & 10 \\
\hline & Medium (4-5) & 61 & 32 \\
\hline & High (5) & 13 & 58 \\
\hline
\end{tabular}


Table.2 Association of soft and social skills with home environment

\begin{tabular}{|c|c|c|c|c|c|c|c|c|c|c|c|c|c|c|c|c|}
\hline \multirow{3}{*}{ Subscale } & \multicolumn{7}{|c|}{ Rural } & & \multicolumn{8}{|c|}{ Urban } \\
\hline & \multicolumn{3}{|c|}{ Soft Skills } & \multirow[t]{2}{*}{$\begin{array}{l}\mathrm{X} 2 \\
\text { Value }\end{array}$} & \multicolumn{3}{|c|}{ Social Skills } & \multirow[t]{2}{*}{$\begin{array}{l}\text { X2 } \\
\text { Value }\end{array}$} & \multicolumn{3}{|c|}{ Soft Skills } & \multirow[t]{2}{*}{$\begin{array}{l}\text { X2 } \\
\text { Value }\end{array}$} & \multicolumn{3}{|c|}{$\begin{array}{l}\text { Social } \\
\text { Skills }\end{array}$} & \multirow[t]{2}{*}{$\begin{array}{l}\mathrm{X} 2 \\
\text { value }\end{array}$} \\
\hline & $\mathbf{L}$ & $\mathbf{M}$ & $\mathbf{H}$ & & $\mathbf{L}$ & M & $\mathbf{H}$ & & $\mathbf{L}$ & M & $\mathbf{H}$ & & & M & $\mathbf{H}$ & \\
\hline \multicolumn{17}{|c|}{ Warmth and Acceptance } \\
\hline Low & 8 & 20 & 1 & \multirow[t]{3}{*}{5.93} & - & 6 & 4 & \multirow{3}{*}{$\begin{array}{l}22.21 * \\
*\end{array}$} & - & - & - & \multirow[t]{3}{*}{0.31} & - & - & - & \multirow[t]{3}{*}{3.14} \\
\hline Medium & 15 & 28 & 8 & & 18 & 18 & 1 & & 3 & 10 & 15 & & 5 & 7 & 15 & \\
\hline High & 3 & 12 & 5 & & 8 & 36 & 9 & & 7 & 22 & 43 & & 5 & 25 & 43 & \\
\hline
\end{tabular}

It was concluded that soft skills were not significantly associated with warmth and acceptance in rural and urban area. Social skills were significantly associated with warmth and acceptance in rural area but, social skills were not significantly associated with warmth and acceptance in urban area. Farren and Ramsycraigh (2013) found that the loving and accepting parent provide a healthy atmosphere for the child to develop his capabilities into proper channels and exercise his potentials to the maximum.

\section{References}

Cunha, F., Heckman; J. J., Lance, L. and Masterov, D., 2006. Interpreting the Evidence on Life Cycle Skill Formation. In E. A. Hanushek and F. Welch (eds.) Handbook of the Economics of Education Vol.1, North Holland, Amsterdam, pp697-812.

Dubrin, A.J., 2014. Leadership: Research Findings. Practice and Skills $4^{\text {th }}$ Ed. Boston, MA: Houghton Mifflin Company, pp-312-314.

Farren, D. and Ramseycraigh, T., 2013. Child development: infant day care and attachment behaviour towards mother and
Teacher, Child development, 48: pp 11216.

Heckman, J. J., J. Stixrud, and S. Urzua (2013):

"The Effects of Cognitive and Noncognitive Abilities on Labor Market Outcomes and Social Behavior," Journal of Labor Economics, 24(3), 411-482.

Herrera, N., Zajonc, R., Wieszorkowska, G. and Cichomski, B. (2003). Beliefs about birth rank and their reflection in reality. Journal of Personality and Social Psychology, 85(1), 142-150.

Knudsen, E. I. (2004). Sensitive periods in the development of the brain and behavior. Journal of Cognitive Neuroscience, 16(1): 1412-1425.

Paulhus, D., Trapnell, P., and Chen, D. (2009). Birth order effects on personality and achievement within families. American Psychological Society, 10(6), 482-488.

Shonkoff, J. P. and Phillips, D., 2010. From Neurons to Neighbourhoods: The Science of Early Child Development. Washington, DC: National Academy Press.

Stewart, A., Stewart, E., and Campbell, L. (2011). The relationship of psychological birth order to the family atmosphere and to personality. Journal of Individual Psychology, 57(4), 363-387.

\section{How to cite this article:}

Poonam Rani and Bimla Dhanda. 2018. Warmth and Affection: A Comparative Study on Soft Skills and Social Skills among Children. Int.J.Curr.Microbiol.App.Sci. 7(06): 922-924. doi: https://doi.org/10.20546/ijcmas.2018.706.109 